\title{
Pemberdayaan Ekonomi Pemuda Melalui Budidaya Jamur Tiram di Dusun Sidowayah, Kecamatan Jambon, Kabupaten Ponorogo
}

\author{
Fuad Fitriawan \\ Fakultas Tarbiyah Institut Agama Islam Sunan Giri Ponorogo \\ fuadfitriawan@gmail.com \\ Dawam Multazamy Rohmatulloh \\ Fakultas Dakwah Institut Agama Islam Sunan Giri Ponorogo \\ dmnusantara@gmail.com \\ Asfahani \\ Fakultas Tarbiyah Institut Agama Islam Sunan Giri Ponorogo \\ fahan380@gmail.com \\ Risa Alfiyah Ulfa \\ Fakultas Tarbiyah Institut Agama Islam Sunan Giri Ponorogo \\ risaalfiyahulfa@gmail.com
}

Naskah diterima: 29 November 2019| Naskah disetujui: 17 Januari 2020

\begin{abstract}
Sidowayah is a hamlet located in Sidoharjo Village, Jambon District. Sidowayah is known as an idiot village, even though actually there are only a few people having mental limitations. On the other hand, Sidowayah is also an area that has advantages both in natural and human resources. The productive age of the Sidowayah community has been on the rise lately, the most prominent is the existence of youth where they have the determination to advance the hamlet, one of them in the economic field. Mushroom cultivation is a long-term plan for them, and therefore better mushroom cultivation training done by university side as proposer plays an important role in realizing these ideals. The training was intended as an initial provision before starting a business. The impact of the training is expected to be able to provide provisions and motivation for young people to start a mushroom cultivation business. In addition, it is expected that the existence of mushroom cultivation can increase assets and the economy of the community of Sidowayah.
\end{abstract}

Keywords: Sidowayah, youth, mushroom cultivation 


\begin{abstract}
Abstrak
Sidowayah adalah sebuah dusun yang terletak di Desa Sidoharjo, Kabupaten Jambon. Sidowayah dikenal sebagai desa idiot, meskipun sebenarnya hanya ada beberapa orang yang memiliki keterbatasan mental. Di sisi lain, Sidowayah juga merupakan daerah yang memiliki keunggulan baik dalam sumber daya alam maupun manusia. Usia produktif masyarakat Sidowayah telah meningkat akhir-akhir ini, yang paling menonjol adalah keberadaan kaum muda di mana mereka memiliki tekad untuk memajukan dusun, salah satunya di bidang ekonomi. Budidaya jamur adalah rencana jangka panjang bagi mereka, dan oleh karena itu pelatihan budidaya jamur yang lebih baik, yang dilakukan oleh pihak universitas sebagai pengusul program pengabdian kepada masyarakat, memainkan peran penting dalam mewujudkan cita-cita ini. Pelatihan ini dimaksudkan sebagai inisiatif awal sebelum memulai bisnis. Dampak pelatihan ini diharapkan mampu memberikan bekal dan motivasi bagi generasi muda untuk memulai usaha budidaya jamur. Selain itu, diharapkan adanya budidaya jamur dapat meningkatkan aset dan ekonomi masyarakat Sidowayah.
\end{abstract}

Kata kunci: Sidowayah, pemuda, budidaya jamur

\title{
Pendahuluan
}

Kabupaten Ponorogo terletak pada koordinat antara $111^{\circ} 17^{\prime}-111^{\circ} 52^{\prime}$ Bujur Timur dan $7^{\circ} 49^{\prime}-8^{\circ} 20^{\prime}$ Lintang Selatan mempunyai wilayah seluas 1.371,78 km² (BPS, 2018:1). Ponorogo secara wilayah termasuk kota kecil di wilayah barat bagian selatan dari Provinsi Jawa Timur. Secara administratif, kota kabupaten ini berbatasan langsung dengan Kabupaten Madiun dan Kabupaten Magetan di sebelah utara, Kabupaten Kediri di sebelah timur, Kabupaten Trenggalek dan Kabupaten Pacitan di sebelah selatan, dan Kabupaten Wonogiri Provinsi Jawa Tengah di sebelah barat. Jumlah penduduknya menurut data BPS 2018 sebanyak 869.894 jiwa, dengan jumlah penduduk laki-laki 434.793 jiwa dan perempuan sebanyak 435.101 jiwa (bps, 2018:4). Sebagai kota kecil yang tidak memiliki laut atau garis pantai dan berada di tengah lembah yang dikelilingi oleh Gunung Lawu, Gunung Wilis, dan pergunungan kecil lain, masyarakat Kabupaten Ponorogo berkembang menjadi masyarakat yang agraris.

Bercocok tanam melalui pertanian atau perkebunan menjadi mata pencaharian yang paling banyak dilakukan oleh masyarakat Kabupaten Ponorogo. Di Ponorogo area persawahan dan perkebunan menurut data ponorogo dalam angka tahun 2018 sebanyak $73.292 \mathrm{Ha}$ dengan hasil panen berupa 458.249 ton padi, 227.610 ton jagung, 535.025 ton ubi kayu dan 6.278 ton kacang tanah (BPS, 2018: 20).

Salah satu dusun yang beberapa tahun menjadi sorotan nasional adalah Dusun Sidowayah yang terletak sekitar $23 \mathrm{~km}$ dari pusat kota Ponorogo. Dahulu, dusun ini berada di wilayah Desa Krebet Kecamatan Jambon Kabupaten Ponorogo Provinsi Jawa Timur. Berdasarkan keinginan dan tujuan yang sama dari masyarakat di wilayah yang lebih jauh dari Balai Desa Krebet, maka pada tahun 2006 Desa Krebet dimekarkan menjadi 2 (dua) desa, yaitu Desa Krebet dan Desa Sidoharjo. Saat itu Desa Sidoharjo masih berstatus definitif (perlu pendampingan). Desa Krebet terbagi mejadi 
5 kampung/dusun, sedangkan Desa Sidoharjo terbagi menjadi 3 kampung/dusun, yaitu Dusun Karang Sengon, Dusun Klitik, dan Dusun Sidowayah. Pada tahun 2008 Desa Sidoharjo diresmikan oleh Bupati Ponorogo, Muhadi Suyono. Jadi, sekarang Dusun Sidowayah bukan lagi bagian dari wilayah Desa Krebet, melainkan bagian dari wilayah Desa Sidoharjo (Fitriawan, 2015:43).

Secara geografis Dusun Sidowayah terletak di bawah kaki Gunung Rajegwesi, arah barat daya Ponorogo, dengan batas-batas: sebelah selatan wilayah Kecamatan Bandar Watu Pathok Kabupaten Pacitan; sebelah timur wilayah Jonggol Kecamatan Jambon, dan Karang Patihan Kecamatan Balong; sebelah barat wilayah Dayakan Kecamatan Badegan; sedangkan sebelah utara wilayah Dusun Klithik dan Karang Sengon Sidoharjo.

Nama Dusun "Sidowayah" muncul karena dahulu di daerah ini banyak tanaman bunga Sidowayah. Wilayahnya termasuk dataran tinggi dan seluruhnya hampir dikelilingi gunung, struktur tanahnya tandus dan miskin kandungan yodium. Penduduk Dusun Sidowayah pada Bulan Juni 2018 telah mencapai lebih kurang 2515 jiwa. Jumlah tersebut lebih banyak dibandingkan dengan jumlah penduduk dua dusun lain di Desa Sidoharjo. Untuk menuju ke wilayah Dusun Sidowayah dibutuhkan waktu lebih kurang 45 - 60 menit dari pusat kota Ponorogo, atau lebih kurang 20 - 30 menit dari kantor Kecamatan Jambon.

Sebagai wilayah yang masyarakatnya bekerja di bidang pertanian, sepengetahuan peneliti, persawahan di Sidowayah mulai tidak ada sekitar tahun 1996. Hal ini disebabkan oleh kecilnya aliran air irigasi karena dari tahun ke tahun volume air sungai terus menyusut akibat penggundulan hutan yang terus terjadi, serta rusaknya kalenan yang membutuhkan biaya tidak sedikit jika diperbaiki. Lahan pertanian di Dusun Sidowayah berubah menjadi lahan kering, cocok ditanami jagung, kedelai, kacang tanah (brol), kacang hijau, kacang panjang, lombok, ketela, padi gogo, jeruk, jambu monyet, mangga, pisang, pepaya, terong, kol (dalam tahap uji coba). Sementara itu, hewan yang biasa diternak warga Dusun Sidowayah adalah sapi, kambing, ayam, dan mentok (wawancara dengan bapak Sukiman).

Dari segi kependudukan, masyarakat Dusun Sidowayah bersifat heterogen karena tidak sedikit warga yang tinggal di daerah ini bukan warga asli. Sebagian warga merupakan warga pendatang dari daerah lain, seperti Ngrandu, Balong, bahkan dari Kabupaten Wonogiri. Hal ini terjadi karena dahulu pada zaman larang pangan (sulit mencari makan), Dusun Sidowayah dianggap masih makmur, sehingga banyak orang datang dari luar dan menetap sebagai warga.

Senyampang dengan kondisi di mana terdapat banyaknya warga yang menderita keterbatasan mental (idiot), di Sidowayah juga terdapat sebuah wadah organisasi bernama Forum Sidowayah Bangkit (FSB) yang dibentuk pada tanggal 18 Agustus 2009, dengan beranggotakan 10 orang, 
meliputi tokoh masyarakat, tokoh agama, pemuda, mahasiswa, dan perangkat desa. Tujuan organisasi ini khususnya untuk menaungi atau menangani masalah orang-orang cacat dan idiot, serta masalah kemiskinan yang ada di Dusun Sidowayah. Saat ini, orang cacat berjumlah 150 orang dan warga miskin pada tahun 2014 berjumlah 604 KK.

Sebagai organisasi besar di sebuah dusun, FSB juga mencakup dua buah anak organisasi, yaitu Forum Sekolah Sangu Akik dan Forum Pesantren Rakyat Al-Hikmah. Forum Sekolah Sangu Akik memiliki tujuan memberikan fasilitas pendidikan nonformal bagi para penduduk khususnya warga Dusun Sidowayah yang masih buta aksara. Sekolah Sangu Akik didirikan pada tahun 2010 oleh seorang pemuda bernama Jarot (almarhum) alias Mbah Kunting. Organisasi ini memiliki beberapa program yaitu pengenalan terhadap lingkungan hidup dalam bentuk pendidikan maupun praktik penanaman 1000 pohon di tahun 2011, 2012, dan 2013. Dalam program tersebut tergabung di dalamnya siswa-siswa sekolah dasar hingga sekolah menengah atas di sekitar Kecamatan Jambon. Berbeda dengan Forum Sekolah Sangu Akik, Forum Pesantren Rakyat Al-Hikmah memiliki program diskusi berbagai bidang mulai masalah keagamaan hingga permasalahan sosial yang dialami oleh masyarakat.

Dalam ranah pendidikan di Sidowayah sendiri terdapat 1 SMK, 2 SDN, 1 RA serta terdapat Madrasah Diniyah Al Fattah dan 2 TPA, dari data tersebut maka ranah pendidikan berpengaruh besar terhadap perkembangan dan kemajuan Dusun Sidowayah.

Dalam lingkup masyarakat khususnya ibu-ibu dan bapak-bapak terdapat jamaah yasinan sebagai wadah penguatan keagamaan, selaian itu kelompok yasinan tersebut merupakan wadah silaturahmi antar warga. Di Dusun Sidowayah itupun terdapat 10 kelompok jamaah yasinan yang menyebar di 13 RT. Selain 4 kelompok tersebut di Sidowayah terdapat berbagai aliran pencak silat, diantaranya SH Terate, Winongo, Pagar Nusa dan Jujitzhu. Meskipun terdapat berbagai macam aliran pencak silat, namun suasana Dusun tetap kondusif karena sudah terwadai dalam PKK seharusnya menjadi motor penggerak bagi ibu-ibu di Dusun Sidowayah akan tetapi peran dan partisipasinya kurang bisa dirasakan oleh masyarakat. Hal serupa juga terjadi pada kelompok tani,meskipun sudah ada akan tetapi peran kelompok tani juga belum bisa dimaksimalkan sepenuhnya oleh masyarakat.

\section{Potensi Aset Sidowayah}

Di dusun Sidowayah banyak terdapat asset-aset potensial yang meliputi aset budaya, aset pendidikan, aset pariwisata, aset kelompok/komunitas, aset kewirausahaan, dan aset keagamaan. 


\section{Aset Budaya}

a. Komunitas Reyog Elar Pitik. Kesenian tradisional yang masih belum terkenal sampai luar desa Sidoharjo. Hal ini terjadi karena kesenian ini sudah jarang ditampilkan. Kurangnya orang dalam pembuatannya menjadi salah satu alasan mengapa kesenian ini jarang ditampilkan. Kesenian Reyog Bulu Ayam ini sudah ada sejak kurang kurang lebih 100 tahun lalu. Tetapi karena reog pada umumnya menggunakan bulu merak dan saat itu bulu merak susah didapat dan harganya juga mahal, maka dibuatlah menggunakan bulu ayam yang mudah didapat dan harganya lebih murah. Setelah membuat keputusan seperti tersebut dan warga menyetujuinya dan dibuatlah reyog bulu ayam. Bulu ayam yang digunakan bisa ayam jenis apa saja, tetapi diambil bagian sayap dan ekornya. Karena bulu bagian sayap dan ekor lebih kuat dan lebih besar ukurannya dibanding bulu yang ada di badan ayam.

b. Pencak Silat ialah sebuah organisasi yang paling besar di kalangan pemuda Sidowayah..

c. Karawitan adalah sebuah grup kesenian yang nantinya bisa dimanfaatkan untuk menghibur masyarakat ketika ada sebuah kegiatan tertentu.

d. Elektone adalah sekelompok pemusik yang memainkan alat music semi modern dan dikelola oleh salah satu pemuda yang mempunyai bakat dalam bidang permusikan, dan dianggotai oleh beberapa dari pemuda yang nantinya dapat dimanfaatkan untuk mengisi berbagai acara yang diadakan dimasyarakat seperti ketika ada hajatan pernikahan, orkesan pada peringatan 17 agustusan, atau berbagai kegiatan lain yang membutuhkan hiburan untuk menghibur para hadirin.

\section{Aset Pendidikan}

Dengan perkembangan zaman di dunia pendidikan yang terus berubah dengan signifikan sehingga banyak merubah pola pikir pendidik, dari pola pikir yang awam dan kaku menjadi lebih modern. Hal tersebut sangat berpengaruh dengan dalam kemajuan pendidikan di Indonesia. Di Dusun Sidowayah sendiri mempunyai beberapa lembaga pendidikan di antaranya 1 PAUD, 1 RA, 2 SDN, 1 SMK dan untuk pendidikan informalnya ada Madrasah Diniyah dan Taman Pendidikan al-Qur'an. Dengan adanya pendidikan tersebut khususnya masyarakat Sidowayah sangat terbantu karena pemikiran pendidikan disana masih sangat minim. Pendidikan tersebut sangat membantu masyarakat Dusun Sidowayah untuk mencetak generasi yang berakal. 


\section{Aset Pariwisata}

a. Bukit Sebrang. Bukit yang terletak di Dusun Sidowayah ini merupakan salah satu wisata alam desa setempat. Wisata ini masih dikelola warga setempat dan belum ada campur tangan dari dinas pariwisata. Bukit Sebrang termasuk wisata yang baru dibuat, dan masih belum banyak orang yang mengetahuinya. Di tempat wisata selain kita disuguhkan oleh pemandangan yang indah dan asri, disediakan pula tempat istirahat seperti gubuk dan warung makan. Gubuk berada di setiap sudut jalur menuju tempat wisata. Yang menarik adalah di setiap gubuk diberi nama dan foto profil tokoh pahlawan nasianal.

b. Sumber Ndawe ialah sebuah tempat yang dahulunya sebagai perairan di masyarakat sekitar terletak di Dusun Sidowayah tepatnya di RT 13. Di Sumber Ndawe ini merupakan tempat yang banyak tumbuh pohon Trembesi yang diperkirakan berusia ratusan tahun, dan di bawahnya mengalir sungai yang jernih.

c. Bendungan Dangkak atau lebih dikenal dengan Embung Dangkak ialah sebuah bendungan seperti danau yang digunakan untuk irigasi atau pengairan oleh masyarakat Desa Sidoharjo.

d. Makam Mbah Gedong ialah sebuah tempat yang terletak di RT 1 dan dipercaya masyarakat untuk melakukan ritual-ritual (doa) permohonan diturunkanya hujan dari sang Khalik. Berbentuk petilasan makam dari seorang wali yang dianggap sebagai sesepuh di Desa Sidoharjo ini.

\section{Aset Komunitas}

a. PKK (Pembinaan Kesejahteraan Keluarga) yang merupakan organisasi kemasyarakatan yang sedang berkembang di Dusun Sidowayah dengan tujuan memberdayakan wanita untuk turut berpartisipasi dalam pembangunan.

b. FSB (Forum Sidowayah Bangkit) merupakan organisasi kepemudaan yang bertujuan dalam peningkatan kemajuan Dusun Sidowayah. Tokoh-tokoh yang paling banyak dalam forum ini adalah para pemuda.

c. Karang Taruna adalah organisasi kepemudaan yang umum ada di Indonesia dan sekarang sedang dikembangkan di Sidowayah. Sebagai wadah untuk mengembangkan generasi pemuda yang nonpartisipan yang didirikan atasa rasa tanggung jawab dan atsa kesadaran dari anggota untuk kesejahteraan social. Berbagai kegiatan yang didirikan oleh pihak karang taruna salah satunya lomba voly antar RT yang dilaksanakan untuk menperingati HUT RI yang ke 73.

d. Kelompok Tani adalah neberapa orang petani atau peternak yang ada di sukuh Sidowayah yang menghimpun diri dalam suatu kelompok karena dianggap memiliki keserasian dalam 
tujuan, motif dan minat. Dengan tujuan untuk menciptakan tata cara penggunaan suberdaya yang ada agar lebih potensial dan dapat dimanfaatkan daengan cermat, yang diarahkan dan dikembalikan manfaatnya untuk rakyat lagi.

\section{Aset Perekonomian}

a. Kolam Pemancingan ialah sebuah sarana untuk menarik para pemuda untuk mengisi waktu luang mereka agar mempunyai kegiatan yang bermanfaat

b. Pembuatan Batako sebagai hasil sampingan pada masyarakat agar tidak mengandalkan SDA yang ada saja

c. Peternakan ialah sebuah sarana usaha bagi para masyarakat untuk memenuhi kebutuhan ekonomi

d. Budidaya Jamur pada awalnya ada salah satu masyarakat yang membudidayakan jamur karena ada kendala di dalam pemasaran maka budidaya jamur tersebut berhenti, dari sini para pemudi tertarik untuk membudidayakan jamur karena melihat hasil dari budidaya jamur yang pernah ada.

\section{Aset Keagamaan}

a. Jamaah Yasin Tahlil di mana sekelompok orang mengadakan rutinan untuk melakukan kegiatan keagaman membaca surat Yasiin dan Tahlil bersama. Dengan adanya kegiatan tersebut, diharapkan agar kedepannya tingkat keagamaan masyarakat di Dusun Sidowayah dapat meningkat. Kegiatan ini dilakukan tiap bakda Shalat Maghrib di Malam Jum'at dengan dipimpin oleh seorang bilal.

b. Ranting NU adalah sebuah kelompok yang berada di bawah naungan Nahdlatul Ulama di tingkat desa dengan berbagai kegiatan yang meliputi khataman rutin tiap Ahad Legi dan berbagai kegiatan lain yang berkaitan dengan ke-NU-an.

\section{Aset sebagai Modal}

Dalam perspektif $A B C D$, aset adalah segalanya. Metode $A B C D$ ini mengajak kita untuk melihat dan menggali informasi kepada masyarakat dari apa yang mereka inginkan dan apa yang nampak dari potensi sumber daya yang ada di masyarakat tersebut, serta pengetahuan, keterampilan dan sumber daya lainnya yang kadang-kadang tersembunyi, dan potensi diatas sering terabaikan atau diberhentikan karena tidak signifikan (Al-Barret, 2013:96-97).

Perlu diketahui bahwa sebenarnya masyarakat di Dusun Sidowayah termasuk masyarakat yang telah mendapatkan beberapa pelatihan dari Dinas Ketahanan Pangan khususnya pada pelatihan 
pembuatan rengginan dari ketela dan pembuatan thiwul instan. Bahkan mereka juga diberi bantuan berupa alat-alat dan keperluan lainya, serta produk yang dihasilkan telah mendapatkan Nomor PIRT yang bahkan pengirimannya sudah mencapai ke luar negeri. Namun demikian, hal tersebut telah berakhir sejak cukup lama dikarenakan kurang telaten dan kurangnya kekompakan dari pihak produsen untuk lebih aktif dalam memproduksi, hingga akhirnya pekerjaan menjadi tertunda dan pesanan yang mulai menurun.

Sedangkan dari pihak pemuda, menurut penulis termasuk dalam kategori yang sudah sangat aktif, ada minat dan ketertarikan yang tinggi terhadap pemberdayaan jamur karena baru dua hari kedatangan kami di desa ini kami langsung diminta untuk merealisasikan angan-angan mereka untuk mengadakan pembudiyaan jamur. Oleh karena itu, kami pun berinisiatif untuk mengadakan pelatihan pemberdayaan jamur. Dan karena pembudidayaan jamur adalah permintaan (dream) dari pihak pemuda Sidowayah, jadi kami lebih memprioritaskan budidaya jamur dibandingkan dengan kemungkinan aset lain.

\section{Pelaksanaan Pelatihan Budidaya Jamur}

\section{Perencanaan}

Setelah kami melihat berbagai potensi yang ada dan menimbang berdasarkan dasar-dasar pemilihan pengembangan potensi yang ada, maka langkah yang kami lakukan adalah mencari seseorang yang mampu dan berpengalaman dalam hal budidaya jamur. Pemateri yang kami nilai mampu membantu dalam pelaksanaan kegiatan budidaya jamur ini adalah Drs. Hamim Himawan, MM yang berasal dari Balong, Ponorogo. Beliau kurang lebih sudah 14 tahun menggeluti bidang tersebut. Sebelum melakukan pelatihan budidaya jamur tiram, kami dan perwakilan pemuda berkunjung langsung ke lokasi pembudidayaan jamur milik beliau. Hal itu kami harapkan agar perwakilan pemuda tersebut mampu memberikan gambaran yang kuat terhadap teman-temannya. Dan hasilnya pun positif, setelah adanya kunjungan langsung ke lokasi para pemuda mempunyai gambaran yang luas mengenai budidaya jamur. Selaian disambut dengan ramah, Bapak Hamim menjelaskan secara detail mengenai pemasaran dan peluang ke depannya. Di sisi lain tidak hanya jamur tiram saja, Bapak Hamim menjelaskan juga mengenai peluang jamur kuping yang pemasarannya mencapai pasar ekspor.

\section{Pelaksanaan}

Pelatihan budidaya jamur ini dilaksanakan pada hari Sabtu, 18 Agustus 2018 yang bertempat di aula gedung Harapan Bangsa Dusun Sidowayah Desa Sidoharjo, dengan jumlah peserta 
kurang lebih sebanyak 45 orang, yang terdiri dari kolompok pemuda dan ibu-ibu yang mewakili masyarakat setempat. Dengan pemateri Bapak Hamim sebagaimana telah direncanakan sebelumnya. Pelaksanan kegiatan ini dimulai setelah dzuhur, dengan pembawa acara mahasiswa INSURI Ponorogo, Agus Trianto dari prodi Pendidikan Guru Madrasah Ibtidaiyah, yang sekaligus membuka kegiatan pelatihan jamur tiram ini. Kemudian dilanjutkan dengan pemateri yang menyampaikan informasi singkat seputar jamur dan jenisnya serta media dan tempat yang cocok digunakan untuk budidaya jamur. Setelah itu pemateri memberikan video singkat yang menjelaskan tentang cara membudidayakan jamur. Dari video tersebut dapat diambil pembelajaran mulai dari pembuatan media, proses fermentasi media tanam, proses sterilisasi, proses inokulasi, proses inkubasi, pembibitan, dan pemeliharan. Kemudian, pemateri menjelaskan serta menunjukkan langsung beberapa media tanam jamur sebagai contoh. Selain diambil jamurnya, Bapak Hamim juga memberikan penjelasan mengenai pemanfaatan limbah baglog (wadah jamur) sebagai pupuk organik yang memiliki kualitas baik.

Selain `pelatihan tersebut, Bapak Hamim juga memberikan tawaran pemasaran kepada para peserta pelatihan, di mana beliau memberikan gambaran pemasaran yang begitu jelas, di antaranya di Pasar Balong yang setiap pagi terdapat sekitar dua ratus penjual sayur keliling yang siap menampung jamur. Semisal satu penjual sayur keliling membeli $1 \mathrm{~kg}$ jamur, maka jamur yang minimal harus disediakan setiap harinya adalah sebanyak $200 \mathrm{~kg}$. Selain pasar Balong, masih banyak lagi pasar yang membutuhkan pasokan jamur.

Pada akhir kegiatan, pemateri memberikan kesempatan kepada peserta pelatihan untuk menanyakan apa yang belum mereka pahami terkait jamur dan pemasarannya. Sebelum kegiatan pelatihan ini ditutup, pemateri memberikan motivasi kepada peserta pelatihan agar pelatihan ini berlanjut dan dapat menjadi media terealisasikannya budidaya jamur di Dusun Sidowayah dan menjadi salah satu sumber perekonomian seperti apa yang masyarakat harapkan. Selain itu, pemateri juga bersedia untuk memberikan pelatihan lanjutan secara langsung yang bertempat di rumah jamur beliau, bimbingan serta pemantauan secara langsung pada proses budidaya jamur yang akan peserta laksanakan.

\section{Hasil}

Setelah menyelesaikan program pengabdian berbasis potensi lokal dengan pendekatan ABCD (Asset Based Community Development) selama satu bulan di Dusun Sidowayah, Desa Sidoharjo, Kabupaten Ponorogo, dapat menghasilkan beberapa hal di antaranya adalah sebagai berikut: 
a. Terlaksananya pelatihan budidaya jamur yang diikuti oleh seluruh pemuda dan perwakilan dari tiap-tiap RT di Dusun sidowayah.

b. Pemberian motivasi untuk pengembangan budidaya jamur oleh praktisi budidaya jamur berpengalaman yang siap berbagi ilmu tanpa pamrih.

c. Penawaran dari pemateri untuk mengadakan pelatihan lanjutan sebagai rencana tindak lanjut proses praktek budidaya jamur yang akan dilaksanakan di rumah pemateri dan dikoordinasi oleh anggota KPM serta diikuti oleh peserta pelatihan dari Dusun Sidowayah.

d. Penawaran dari pemateri untuk pemasaran hasil budidaya jamur dari peserta pelatihan.

e. Pelatihan lanjutan tetang pemanfaatan limbah dari baglog yang sudah tidak dipakai untuk dijadikan pupuk organik (molase)

\section{Dampak}

Pelaksanaan KPM berbasis potensi lokal dengan pendekatan ABCD (Asset Based Community Development) di Dusun Sidowayah dengan memperhatikan semua tahapantahapan di dalammya, dapat menghasilkan dampak yang cukup baik diantaranya:

a. Terciptanya pemuda yang mempunyai semangat juang dalam berkarya dan mengembangkan diri dalam wirausaha.

b. Terlaksananya pelatihan budidaya jamur yang diikuti oleh pemuda dan perwakilan dari tiap-tiap RT se-Dusun Sidowayah.

c. Antusiasme yang tinggi dari peserta pelatihan dalam mempelajari wirausaha bidang budidaya jamur.

d. Mendapat sambutan yang positif dari masyarakat terutama pemuda Dusun Sidowayah terkait adanya pelatihan jamur.

e. Pemuda Dusun Sidowayah juga siap mengikuti proses latihan lanjut di tempat pemateri.

\section{Refleksi}

\section{Pemuda}

Pemuda Dusun Sidowayah memiliki karakter yang solidaritas yang sangat tinggi, aktif, dan mempunyai semangat untuk berwirausaha yang sangat tinggi. Terlihat ketika mengikuti kegiatan pelatihan budidaya jamur yang diadakan, mereka aktif dalam bertanya terkait materi yang disampaikan oleh pemateri, semangat dalam mengembangkan diri untuk lebih maju. Kedatangan dan keikutsertaan kami dalam setiap kegiatan yang diadakan diterima dengan 
sangat baik oleh para pemuda, dan mereka berharap peserta KPM bersedia membantu masyarakat terutama dalam bidang kewirausahaan, sebab pengetahuan wirausaha dalam budidaya jamur di wilayah ini tergolong minim terlebih sebelumnya mereka pernah melakukan budidaya jamur namun berhenti dikarenakan minimnya ketelatenan dan cuaca yang kurang mendukung (tandus/gersang) dalam musim kemarau.

\section{Tokoh Masyarakat}

Tokoh masyarakat di Dusun Sidowayah sangat antusias dan sangat berterima kasih atas seluruh kontribusi yang telah diberikan kepada masyarakat, baik berupa tenaga, fikiran dan lain-lain. Tokoh masyarakat sangat berharap agar hubungan silaturrahmi antara masyarakat Dusun Sidowayah dengan anggota KPM INSURI Ponorogo dapat berkelanjutan.

Para tokoh masyarakat selalu menanti dan mengharapkan kedatangan kami meskipun hanya sekedar silaturrahmi sekaligus melihat perkembangan budidaya jamur khususnya para pemuda yang tengah bersemangat dalm berbudidaya jamur yang akan dibantu proses lanjutannya di tempat pemateri.

\section{Masyarakat Umum}

Masyarakat Dusun Sidowayah mengucapkan banyak terima kasih kepada peserta KPM karena kedatangannya banyak membantu masyarakat khususnya di bidang budidaya jamur. Mereka juga merasa kehilangan karena seiring berjalannya waktu kegiatan-kegiatan kami akan berakhir, begitu pula kebersamaan kami dengan masyarakat. Akan tetapi kami maupun masyarakat berharap agar tali persaudaraan kami tetap terjalin dengan baik dan dapat bertemu kembali di lain kesempatan.

Rasa kehilangan tersebut tampak pada saat kami mengikuti kegiatan rutinan Yasinan terakhir, sebagai wakil dari masyarakat Ibu dan bapak Ketua Jama'ah Yasinan mengucapkan banyak terima kasih atas kegiatan yang kami laksanakan di Dusun Sidowayah dan merasa sedih serta keberatan harus segera berpisah dengan kami.

\section{Simpulan}

Pada pengabdian masyarakat selama satu bulan di Dusun Sidowayah, desa Sidoharjo, kabupaten Ponorogo, dengan pendekatan ABCD (Asset Based Community Development), masyarakat tempatan memiliki beberapa potensi yang dapat dikembangkan, namun dengan menimbang dan mengacu pada kebutuhan, kami lebih menitikberatkan pada potensi prioritas yaitu 
mengadakan pelatihan pembudidayaan jamur. Setelah diadakannya pelatihan tersebut, pemuda mempunyai semangat dan kemauan yang kuat untuk berwirausaha budidaya jamur, di mana pemateri juga memberi motivasi yang sangat membangun mental para pemuda.

\section{Pernyataan}

Tulisan ini merupakan serpihan kecil dari beberapa tulisan peneliti mengenai Sidowayah, yaitu mengenai penelitian kualitas air di Dusun Sidowayah dan mengenai kearifan lokal dalam rangka konservasi DAS dan Sumber Mata Air. Ucapan terima kasih peneliti ucapkan kepada Kepala Desa Sidoharjo, Kamituwo Sidowayah, dan seluruh lapisan masyarakat yang telah mendukung terlaksananya program pengabdian masyarakat ini hingga usai.

\section{Daftar Pustaka}

Barrett, A. (2013). Asset-Based Community Development: A Theological Reflection, Birmingham: Vicar Of Hodge Hill Church.

Badan Pusat Statistik Kabupaten Ponorogo. (2018). Statistik Daerah Kabupaten Ponorogo 2018. Ponorogo: Azka Putra Pratama

Dureau, C. (2013), Pembaru dan Kekuatan Lokal untuk Pembangunan, Australian Community Development and Civil Society Strengthening Scheme (ACCESS) Tahap II, hal. 96-97.

Fitriawan, F. (2015). "Kearifan Lokal Masyarakat Kampung Idiot dalam Upaya Mengembalikan Daerah Aliran Sungai dan Sumber Mata Air Dusun Sidowayah Desa Sidoharjo Kecamatan Jambon Kabupaten Ponorogo". QALAMUNA - Jurnal Pendidikan, Sosial, dan Agama, Vol 7 No 1. 